\title{
Logistics performance as a mediator of the relationship between trade facilitation and international trade: A mediation analysis
}

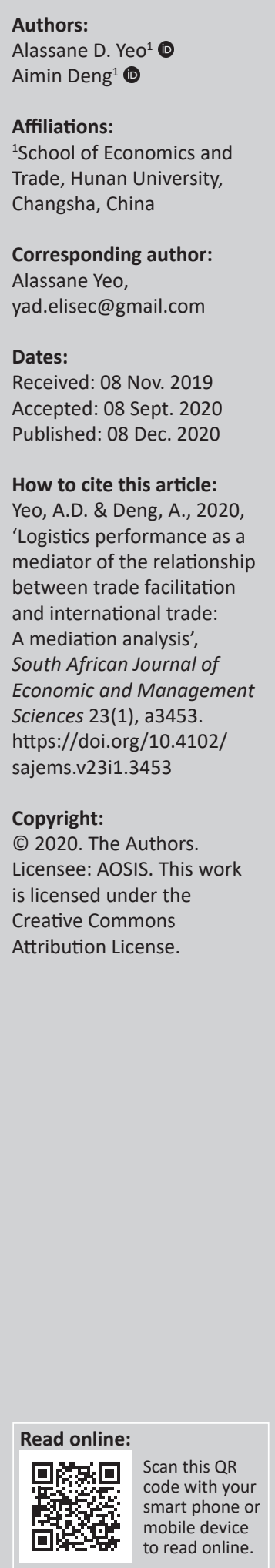

Background: The development of services, infrastructure and logistics has contributed in reducing costs and delays in exchanges between countries, leading to a significant increase in global trade.

Aims: To provide empirical evidence of the relationship between trade facilitation and international trade through logistics performance.

Settings: We collected data every 2 years - 2010, 2012, 2014, 2016 and 2018 - over 8 years from 62 countries, including 33 lower-middle-income countries and 29 upper-middle-income countries.

Methods: Structural equation modelling is used to analyse the structural relationships between measured variables and latent constructs.

Results: Using mediation analysis, the results reveal a positive and statistically significant relationship between trade facilitation and international trade through logistics performance.

Conclusion: The results draw the attention of policy makers that improved logistics performance facilitates the movement of goods and services between countries for both importers and exporters. Lower middle-income countries should encourage cooperation between the public and private sectors and focus their efforts on all aspects of the development of transport infrastructure services to improve the efficiency of international trade.

Keywords: trade facilitation; international trade; logistics performance; mediation; analysis.

\section{Introduction}

The growing volume of international trade, the disappearance of borders between countries and the expansion of the concept of globalisation have recently made the logistics sector more important in world trade. Today, logistics has emerged as one of the largest and most dynamic activities in the world. Unfortunately, the logistics gap between rich and poor countries persists. According to the Logistics Performance Index (LPI), high-income countries dominate the logistics ranking, while the worst performers are underdeveloped economies that are often landlocked countries, small island states or post-conflict countries. However, logistics performance is not merely determined by the level of per capita income, as many countries perform better than others in different income groups. When talking about logistics performance, Gani (2017) refers to the processes necessary for the safe and secure transport of goods from one country to another. Underdeveloped and developing countries, therefore, need practical trade logistics measures to facilitate trade in order to change import and export processes and optimise the supply chain without having to commit to significant additional human and financial resources.

Trade facilitation refers to the transparency and efficiency of international trade procedures aimed at reducing the time and cost of international trade transactions (Portugal-Perez \& Wilson 2012). It is a broad concept that can be applied to the entire supply chain as a whole and, in particular, to the logistics. Previously considered a highly technical field, specifically for customs specialists at the border, trade facilitation is now a central element of trade and development strategies. This change in perception is seen in recent studies which have shown that the costs associated with trade in goods - border procedures, documentary requirements, delays and logistical costs - are likely to increase considerably (Ariekot 2018; Hausman, Lee \& Subramanian 2013) 
The relationships between trade facilitation, logistics performance and international trade are many and varied. International trade involves the movement of capital, commodities and services between countries (Paruzel 2018). Countries specialise in exporting those products and services that they can produce most efficiently and import those in which they are less efficient. Logistics is about managing the activities along in a supply chain, from procuring materials to delivering finished goods that satisfy customer orders (Pagel 1999). Adequate logistics and supply chain management (SCM) are, therefore, the key enablers of international trade. Efficient infrastructure services lower transaction costs, raises added value and increase performance while strengthening connections with global supply chains and distribution channels for producers (Pérard 2009). Logistics services play a crucial role, and the challenges of efficient logistics are increasing as countries move towards higher value-added manufacturing and production processes become increasingly sophisticated and complex.

There are several studies on applying mediation models to examine the relationships among variables in various fields. Meyer and Catherine (2000) applied structural equation modelling (SEM) analyses to examine the mechanisms involved in observed relations between human resource management (HRM) practices and employee commitment. Alfes et al. (2013) also developed and tested a moderated mediation model linking perceived HRM practices to organisational citizenship behaviour and turnover intentions. Fairchild and MacKinnon (2009) present a general model that simultaneously estimates the effects of mediation and moderation, and describe methods for testing the effects of mediation and moderation in a data set, both together and separately. Cromley and Azevedo (2007) tested the fit of the model and three variants of the model to data from 175 Grade 9 students and discussed the direct and indirect effects of these five predictors on reading comprehension. Indeed, the model hypothesises the relationships between background knowledge, inferences, reading comprehension strategies, vocabulary and word reading.

This study aims to provide empirical evidence of the relationships between trade facilitation on international trade through logistics performance. To do so, firstly, SEM conceptualises a theoretical causal model consisting of a set of predicted covariances between variables and tests whether it is plausible when compared to the observed data (Jöreskog 1970). Then, the mediation analysis is used to obtain the indirect analysis of trade facilitation on international trade through logistics performance and test whether it is statistically significant or not. Figure 1 describes the hypothetical model for the study.

The rest of the article is structured as follows: the next section reviews the literature and hypotheses development, the third section describes the research methodology and the following section provides the results of different tests. Then we discuss implications and limitations, which is followed by the conclusion.

\section{Research questions}

This research attempts to address the following questions:

- Does trade facilitation have a significant relationship with international trade?

- Does trade facilitation have a significant relationship with logistics performance?

- Does logistics performance have a significant relationship with international trade?

- Does logistics performance mediate the relationship between trade facilitation and international trade?

\section{Literature review and hypotheses} Trade facilitation and international trade

Trade facilitation focuses on simplifying and harmonising trade procedures through reduced transport costs (Behar \& Venables 2011), efficient customs procedures (Messerlin \& Zarrouk 2000), transparent and harmonised regulations (Wilson \& Otsuki 2003) and improved information technology infrastructure (Stone \& Strutt 2010). In recent years, the notion of trade costs has been widely discussed in the literature on international trade. Milner, Morrissey and Zgovu (2008) identify the types of trade facilitation reforms that could address transport, distribution and communication issues and produce results in terms of improving the efficiency of revenue collection, reducing trade costs and promoting greater regional cooperation in the areas of customs and transport costs. Pomfret and Sourdin (2010) identified, apart from distance-related transport costs, port efficiency and regulatory charges, the difference between cost, insurance and freight (CIF), and free on board (FOB) as the best aggregate measure of trade costs, which unfortunately suffers from a lack of data consistency.

The main target of trade facilitation is to increase international trade. Clark, Dollar and Micco (2004) studied the determinants of shipping costs to the United States using an extensive database of more than $300 \quad 000$ observations per year on shipments of products aggregated at the six-digit Harmonized System level from various ports around the world. They found that a reduction in inefficiencies in transport costs can result in an increase in bilateral trade of countries to the United States. Iwanow and Kirkpatrick (2007) identified that a 10\% improvement in trade facilitation would lead to an increase in exports of about $5 \%$. Their findings suggest that while trade facilitation

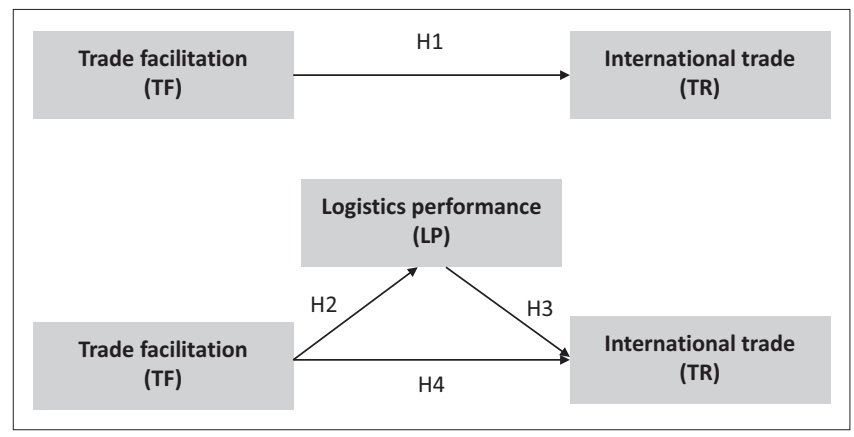

FIGURE 1: Conceptual framework. 
can contribute to improving export performance, improving the quality of the regulatory environment, basic transport and communications infrastructure are also essential in facilitating export growth. Wilson, Mann and Otsuki (2005) constructed four indicators to a larger set of countries and used econometric estimates from a gravity model to show that improved trade facilitation in a sample of 75 countries could increase trade by $10 \%$, or $\$ 377$ billion. MartinezZarzoso and Márquez-Ramos (2008) used an augmented gravity equation to estimate data collected from the World Bank's Doing Business database of 13 exporters and 167 importers using several estimation techniques, namely ordinary least squares, personalized print markup language and the Harvey model. The results indicate that the reduction in transport costs and the number of days required for import and export would lead to an increase in the volume of trade flows. Based on previous studies, we hypothesised that:

H1: Trade facilitation has a positive and significant relationship with international trade

\section{Trade facilitation and logistics performance}

Assessment of logistics performance, including customs and border controls, are key elements of trade facilitation. Lakshmanan (2011) suggests that investment in port infrastructure can improve a country's logistics performance. As a result, the port offer has a positive effect on demand, and the added value of the port-related activity can have a positive impact on the development of the regional economy (Gonçalves \& Assumpção 2016). They believe that better technology and modern equipment to ensure higher reliability, less damage, the ability to track and trace shipments would contribute to improving a country's logistics performance. Weerahewa (2009) uses gravity models of the exports of five product categories, that is, all food and agriculture, live animals, vegetables, processed food and manufactured products, to show that significant trade gains can be achieved by reducing border inefficiencies in south Asia. These gains for trade have been further demonstrated by Portugal-Perez and Wilson (2009), who argue that African exporters who reduce their trade costs midway through Mauritius have a greater effect on trade flows than a substantial reduction in tariff barriers.

Raballand et al. (2012) have highlighted the long duration of goods in different ports. The impact of downtime on trade has recently been identified as a major obstacle to the development of low-income countries. They also indicate that ports in sub-Saharan Africa have an average of more than 2 weeks of downtime, adding that this not only affects the efficiency but also aggravates the congestion situation with its cost implications for the economy. Also, Yang and Chang (2019) identified transport capacity, external risks, information integration, logistics infrastructure, logistic capacity of local agents and national laws and policies as the determining factors for logistics operations in landlocked African countries. Hence the following hypothesis:

H2: Logistics performance has a positive and significant relationship with trade facilitation

\section{Logistics performance and international trade}

The Global Enabling Trade Report (2014) suggested that improving logistics key components can result in an increase of up to $4.7 \%$ in gross domestic product (GDP) and $14.5 \%$ in global trade. This argument is supported by Banister and Berechman (2001), who have indicated that better logistics stimulates growth, competitiveness and investment. Puertas, Martí and García (2014), in their work on the importance of logistics performance in the European Union exports during the period 2005-2010, have identified the important role that logistics plays in competitiveness. Korinek and Sourdin (2011) estimate the effect of the various proxies for trade logistics quality on bilateral trade to quantify how logistics quality influences trade flows using the logistics proxies outlined above for 2008, after controlling for other trade cost measures and determinants of bilateral trade. This article investigates the role that trade logistics plays in the volume and value of international trade and the extent to which poor-quality logistics constitute a barrier to trade. Itakura (2014) identified three key components affecting international trade: the reduction of tariffs on goods, the reduction of trade barriers in services and the saving on time costs. Although liberalisation through reducing trade barriers has a significantly positive impact on economic welfare, logistics is indeed essential in determining the trade flows of goods (Bensassi et al. 2015). So, the present hypothesis is:

H3: Logistics performance has a positive and significant relationship with international trade

\section{Trade facilitation, logistics performance and international trade}

Simultaneous research on the relationship between trade facilitation, logistics performance and international trade remains limited as most of the work includes logistics performance as an integral part of trade facilitation. In her work, Mann (2012) identified trade facilitation as the policy analysis of impediments to global sourcing and multinational supply chains. Research on trade facilitation provides a macroeconomic overview of how policymakers should change the business environment to promote international trade and economic growth. In contrast, logistics provides the microeconomic perspective of the supply chain and examines how a company should organise its operations in light of the policy environment.

Trade facilitation and logistical support are two effective ways to facilitate the flow of goods and services between importers and exporters. Wilson et al. (2005) measured and estimated the relationship between trade facilitation and trade flows, considering four important categories: port infrastructure (air and maritime), customs environment, regulatory environments and e-business infrastructure. The results suggest that reform and capacity building in trade facilitation could significantly increase trade and exports. Njinkeu, Wilson and Fosso (2008) also analysed the impact trade facilitation has on export by constructing four indicators to which are included the performance logistics indicators: port efficiency, customs environment, regulatory 
environment and service infrastructure. These same indicators have also been constructed for logistics performance in other studies, for example, Martí, Puertas and García (2014) used the LPI to analyse differences between countries in terms of customs procedures, logistics costs and the quality of the infrastructure for overland and maritime transport. The results show that improvements in one of the components of LPI can lead to a significant growth in trade flows in many countries in Africa, South America and eastern Europe. The quality and efficiency of logistics services can be a major advantage for international trade, in the same way as weak logistics infrastructure and operational processes can be a major obstacle to global trade integration (Devlin \& Yee 2005). Otherwise, improved trade-related logistics, combined with a liberalised economic environment, can increase trade volume and economies of scale and scope in distribution and production activities (Lakshmanan et al. 2001). Given the above, the idea of logistics as a mediator between trade facilitation and international trade could be verified. So, the fourth hypothesis is as follows:

H4: Trade facilitation has a positive and significant relationship with international trade mediated through logistics performance.

\section{Methodology \\ Data}

This study adopted the SEM method widely used when it is a question of constructing the latent variable. We collected data from 62 countries, including 33 lowermiddle-income and 29 upper-middle-income countries (Appendix 1). To meet the criterion that a sample size for complex should be more than 100 (Kline 2005), we pooled the data over five time periods, namely 2010, 2012, 2014, 2016 and 2018, and therefore obtained 310 observations necessary and sufficient for our analysis as predicted (Hoogland \& Boomsma 1998; Muthén \& Muthén 2002; Tinsley \& Tinsley 1987).

The summary of demographics is outlined in Table 1. The majority of the countries in our database (57.1\%) have a GDP under $\$ 100$ billion. Most of them have an estimated population of under 50 million $(71.4 \%)$. The frequency distribution also shows that $9.7 \%$ of the countries present have a GDP below $\$ 10$ billion and above $\$ 1$ trillion, and $48.4 \%$ have a GDP between $\$ 10$ billion and $\$ 100$ billion. Four continents are represented in our database: Africa 24.4\%, Asia 31.7\%, America 27.4\% and Europe 16.1\%.

\section{Dependent variable}

The importance of international trade in the global market was revealed earlier by political economists such as Ricardo (1817) and Smith (1776). International trade, therefore, enables consumers and countries to access goods and services that are either not available to them or are not in sufficient quantities at the local level.

Two variables - export and import - measure international trade. The remaining dependent variables were all obtained
TABLE 1: Summary of demographics.

\begin{tabular}{lcc}
\hline Variable & Frequency & $\%$ \\
\hline Income & 33 & 53.2 \\
Lower-middle income & 29 & 46.8 \\
Upper-middle income & & \\
Population (million inhabitants) & 24 & 38.7 \\
Under 10 & 21 & 33.9 \\
$11-50$ & 7 & 11.3 \\
51-100 & 8 & 12.9 \\
101-1000 & 2 & 3.2 \\
Over 1001 & & \\
Gross domestic product (US\$ billion) & 6 & 9.7 \\
Under 10 & 30 & 48.4 \\
11-100 & 20 & 32.3 \\
101-1000 & 6 & 9.7 \\
Over 1001 & & \\
Countries group & 16 & 25.8 \\
Africa & 19 & 30.6 \\
Asia & 17 & 27.4 \\
America & 10 & 16.1 \\
Europe & &
\end{tabular}

from the World Bank database. Export is the selling of goods and services from the country of origin to a foreign country. At the same time, import refers to the purchase of foreign products and then bringing them to the country. Nations have specific resources and capacities; for example, some countries are rich in natural reserves, others in technology and human capital. The needs of countries to import and export are, therefore, essential to the functioning and growth of nations.

The shares of trade, exports and imports in GDP are widely used in the literature and are found to be significantly and positively correlated with growth (Kali, Méndez \& Reyes 2007; Yanikkaya 2003).

\section{Mediating variables}

Logistics performance is considered as a component indicator of trade facilitation (Martí et al. 2014). Many studies consider logistics performance to be the new leader in SCM, for example Bolumole (2001) indicates that the role of service providers in the logistics strategy and the logistics process facilitates supply chain solutions. In our case, logistics performance is measured by the six indicators given by the World Bank LPI. These include the following: the efficiency of the clearance process or customs (speed, simplicity and predictability of formalities), quality of trade and transportrelated infrastructure (ports, railroads, roads and airports), ease of arranging competitively priced shipments, competence and quality of logistics services (transport operators, customs brokers), ability to track and trace consignments, and timeliness of shipments in reaching the destination within the scheduled or expected delivery time. All measurements were captured in the World Bank database on a scale of 1 (low) to 5 (high) initially and rescaled on a scale of 0 to 1 .

\section{Independent variables}

Four variables were constructed following those elaborated by Portugal-Perez and Wilson (2012) to measure the concept 
of trade facilitation. Physical infrastructure refers to the physical network necessary for the functioning of the modern industry. It includes roads, railways, ports and airports. Information and communication technology is the set of technologies used to manage telecommunications, broadcast media, intelligent building management systems, broadcasting processing and transmission systems, and network control and monitoring functions. The efficiency of borders and transport is controlled from export time (the time required to comply with all procedures required to export goods), export documentation (a number of documents that must be prepared by the exporter in order to organise the export of his shipments) and cost to export (cost measures the duties collected on a 20 -foot container in US dollars). The institutions are based on data available from the World Economic Forum global competitiveness index. The institution's measure is government regulation, irregular payments and bribes, the prevalence of bribes, the prevalence of commercial bribes and the transparency of government policymaking.

\section{Data analysis and results Statistical method}

We use exploratory factor analysis (EFA) and confirmation analysis (CFA) to conduct reliability, validity and descriptive analysis. The SEM technique was used to test the hypothesis; IBM SPSS AMOS software version 22 was used to conduct data analysis.

\begin{tabular}{llc} 
TABLE 2: Kaiser Meyer-Olkin and Bartlett's test. & \\
\hline Test & Variable & Value \\
\hline $\begin{array}{l}\text { Kaiser-Meyer-Olkin measure of } \\
\text { sampling adequacy }\end{array}$ & - & 0.886 \\
Bartlett's test of sphericity & Approximate chi-square & 2166.725 \\
& $d f$ & 45 \\
& Significance & 0.000 \\
\hline
\end{tabular}

\section{Data measurement model}

We conducted several tests to verify the validity and reliability of the variables. First, we used Kaiser MeyerOlkin (KMO) and Bartlett to indicate the proportion of variance in our variables that could be caused by underlying factors. The results presented in Table 2. show that the KMO of the sampling adequacy is 0.886, which is less than 0.90; therefore, it is barely acceptable (Kaiser 1974). Bartlett's sphericity test with a value of 0.000 (less than 0.05) attests that the correlation matrix is an identity matrix. Moreover, factor analysis can be useful with the data. In Table 2, the correlation coefficient indicates the strength of the relationships between all the latent variables, which means that there is a positive and significant positive correlation between the variables. Exports have a positive and significant correlation with imports $(r=0.996, p<0.05)$. The two variables are extremely strongly related, while many of the other variables are weakly related.

Table 3 presents the results of the evaluation of the measurement model; as indicated by Drolet and Morrison (2001), high reliability is generally desirable. Common criteria for measuring the reliability of construction variables such as Cronbach's alpha and composite reliability (CR) have values between 0 and 1 , and should be as high as possible to indicate excellent reliability. The result obtained showed that the $C R$ of the latent variable on logistics performance, trade facilitation and international trade was $0.928,0.802$ and 0.900 , and the Cronbach's alpha coefficients were $0.933,0.921$ and 0.998 , which is desirable because it indicates almost perfect reliability of the measurements. Considering that the saturation coefficient was higher than the accepted threshold of 0.7 (Cronbach 1951) and that the average variance extracted (AVE) was higher than the threshold of 0.5 (Bagozzi \& Phillips 1991), we then validated our latent measurements.

TABLE 3: Reliability, validity, correlation and description statistics of the variables.

\begin{tabular}{|c|c|c|c|c|c|c|c|c|c|c|c|c|}
\hline Variable & EXP & IMP & INF & ICT & EBT & INS & CUS & QTI & EIS & LOG & ETT & TIM \\
\hline EXP & 1 & - & - & - & - & - & - & - & - & - & - & - \\
\hline IMP & $0.996 * *$ & 1 & - & - & - & - & - & - & - & - & - & - \\
\hline INF & $0.274 * *$ & $0.283^{* *}$ & 1 & - & - & - & - & - & - & - & - & - \\
\hline ICT & $0.115^{*}$ & 0.112 & $0.476 * *$ & 1 & - & - & - & - & - & - & - & - \\
\hline EBT & 0.034 & 0.054 & $0.350 * *$ & $0.314 * *$ & 1 & - & - & - & - & - & - & - \\
\hline INS & $0.177^{* *}$ & $0.183 * *$ & $0.647^{* *}$ & $0.424 * *$ & $0.283^{* *}$ & 1 & - & - & - & - & - & - \\
\hline QTI & $0.488 * *$ & $0.503 * *$ & $0.505^{* *}$ & $0.465 * *$ & $0.304 * *$ & $0.387 * *$ & $0.823 * *$ & 1 & - & - & - & - \\
\hline EIS & $0.378 * *$ & $0.394 * *$ & $0.407 * *$ & $0.405 * *$ & $0.319 * *$ & $0.267 * *$ & $0.664 * *$ & $0.709 * *$ & 1 & - & - & - \\
\hline LOC & $0.449 * *$ & $0.470 * *$ & $0.459 * *$ & $0.403 * *$ & $0.388 * *$ & $0.307 * *$ & $0.735 * *$ & $0.825 * *$ & $0.731 * *$ & 1 & - & - \\
\hline ETT & $0.406 * *$ & $0.425 * *$ & $0.381 * *$ & $0.362 * *$ & $0.343 * *$ & $0.229 * *$ & $0.612 * *$ & $0.733^{* *} *$ & $0.690 * *$ & $0.834 * *$ & 1 & - \\
\hline TIM & $0.341 * *$ & $0.355^{* *}$ & $0.292 * *$ & $0.301 * *$ & $0.336^{* *}$ & $0.259 * *$ & $0.508 * *$ & $0.631 * *$ & $0.651 * *$ & $0.734 * *$ & $0.787^{* *}$ & 1 \\
\hline Mean & 0.037 & 0.041 & 0.506 & 0.510 & 0.756 & 0.553 & 0.399 & 0.446 & 0.516 & 0.460 & 0.608 & 0.592 \\
\hline Standard deviation & 0.112 & 0.116 & 0.173 & 0.148 & 0.165 & 0.145 & 0.159 & 0.183 & 0.189 & 0.186 & 0.138 & 0.126 \\
\hline Composite reliability & 0.900 & - & 0.802 & - & - & - & 0.928 & - & - & - & - & - \\
\hline Average variance extracted & 0.819 & - & 0.517 & - & - & - & 0.685 & - & - & - & - & - \\
\hline Cronbach's $\alpha$ & 0.998 & - & 0.921 & - & - & - & 0.933 & - & - & - & - & - \\
\hline
\end{tabular}

EXP, export; IMP, import; INF, physical infrastructure; ICT, information and communication technologies; EBT, efficiency of borders and transport; INS, institution; CUS, customs; QTI, Quality transport infrastructure; EIS, Ease of international shipments; LOC, logistics competence; ETT, tracking and tracing; TIM, timeliness.

*, Correlation is significant at the 0.05 level (two-tailed); **, Correlation is significant at the 0.01 level (two-tailed). 


\section{Hypothesis testing}

The SEM analysis approach will be used to provide model fit information that provides information about the consistency of the hypothesised mediational model to the data. It also eliminates the measurement error in estimating the relationships between variables. The chi-square of 248.727, degree of freedom of 51 and $p$ value of 0.00 indicate that the model fits the data according to sample size. The goodness of fit index (GFI $=0.934)$ and the root-meansquare error approximation $($ RMSEA $=0.096)$ confirmed a good fit (see Table 4).

A series of hypotheses were used to test the relationships between latent construction. The results and their significance are presented in Table 5. The first hypothesis revealed a negative and insignificant relationship between trade facilitation and international trade $(\beta=-0.048 ; P=$ 0.481 ), indicating that better trade facilitation leads to a reduced volume of international trade. The second hypothesis revealed a significant relationship between trade facilitation and logistics performance $(\beta=0.609 ; P<$ $0.001)$, indicating that better trade facilitation is associated with better logistics performance. The same result was

TABLE 4: Results of the goodness of fit indices for the measurement model.

\begin{tabular}{lcc}
\hline Goodness of fit statistics & $\begin{array}{c}\text { Measurement } \\
\text { model }\end{array}$ & Recommended values \\
\hline$x^{2} / d f$ & 4.877 & $<3, n<150 ;<5, n>200$ \\
Root-mean-square error approximation & 0.096 & $<0.08$ \\
Goodness of fit index & 0.934 & $>0.90$ \\
Normed fit index & 0.922 & $>0.95$ \\
\hline
\end{tabular}

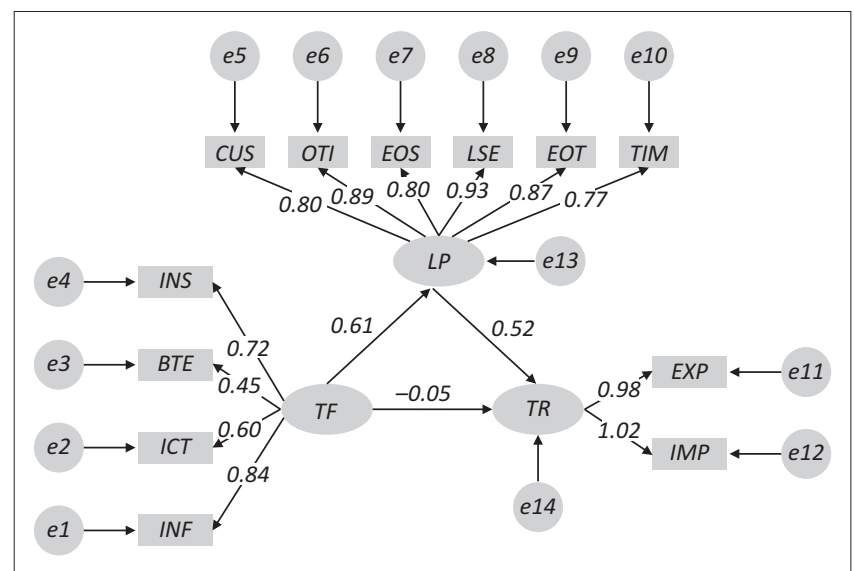

EXP, export; IMP, import; INF, physical infrastructure; ICT, information and communication technologies; EBT, efficiency of borders and transport; INS, institution; CUS, customs; QTI, Quality transport infrastructure; EIS, Ease of international shipments; LOC, logistics competence; ETT, tracking and tracing; TIM, timeliness.

Note: Trade facilitation (TF), logistics performance (LP) and international trade (TR) latent variables; from INS to IMP observed indicators; numbers represent standardised estimates

FIGURE 2: Measurement model. obtained for the third hypothesis, meaning that logistics performance has a positive and significant effect on international trade $(\beta=0.524 ; P<0.001)$. The final hypothesis showed the positive and significant effect of trade facilitation on international trade through logistics performance $(\beta=0.240 P<0.001)$, indicating that trade logistics performance mediated the effects of trade facilitation on international trade. Thus, H2, H3 and H4 are supported, and $\mathrm{H} 1$ is not supported.

\section{Mediating effect of logistics performance}

We analyse mediation following Baron and Kenny's (1986) steps and test the significance through Sobel's (1990) test and bootstrapping. The basic steps in mediation analysis suggested by Baron and Kenny are as follows. The mediation analysis is conducted using three regression sets: $\mathrm{X} \rightarrow \mathrm{Y}, \mathrm{X} \rightarrow \mathrm{M}$ and $\mathrm{X}+\mathrm{M} \rightarrow \mathrm{Y}$. In examining a mediational hypothesis, the relationship between an independent variable and a dependent variable is decomposed into two causal paths (Alwin \& Hauser 1975). One of these paths links the independent variable $(X)$ to the dependent variable ( $Y$ ) directly (the direct effect), and the other links the independent variable to the dependent variable through a mediator $(\mathrm{M})$ (the indirect effect). An indirect or mediated effect implies that the independent variable causes the mediator, which, in turn, causes the dependent variable (Sobel 1990).

To examine the mediation effects of logistics performance on international trade. We consider logistics performance as the mediator (M), trade facilitation as the independent variable $(X)$ and international trade as the dependent variable $(\mathrm{Y})$ :

- $a=$ raw regression coefficient for the association between $\mathrm{X}$ and $\mathrm{M}$ (unstandardised).

- $s_{\mathrm{a}}=$ standard error of $a$.

- $b=$ raw regression coefficient for the association between $\mathrm{M}$ and the $\mathrm{Y}$ (when the $\mathrm{X}$ is also a predictor of the $\mathrm{Y}$ ).

- $s_{\mathrm{b}}=$ standard error of $b$.

The results presented in Table 6 show the existence of a strong causal indirect relationship between trade facilitation and international trade. To support the idea of a mediator effect, testing mediation using the bootstrapping has been done. We found a significant indirect effect that varies from 0.0325 to 0.1543 , with an estimated effect of 0.0935 over a $95 \%$ confidence interval. The remaining direct, indirect and total effects are presented in Table 7.

TABLE 5: Hypotheses testing summary.

\begin{tabular}{|c|c|c|c|c|c|c|}
\hline Path description & Standardised estimates & Standard error & Composite reliability & Hypothesis & $p$ & Results \\
\hline $\mathrm{TF} \rightarrow \mathrm{TR}$ & -0.048 & 0.049 & -7.728 & $\mathrm{H} 1$ & 0.481 & Rejected \\
\hline$T F \rightarrow L P$ & 0.609 & 0.059 & 9.033 & $\mathrm{H} 2$ & $*$ & Accepted \\
\hline$L P \rightarrow T R$ & 0.524 & 0.061 & 7.358 & $\mathrm{H} 3$ & $*$ & Accepted \\
\hline $\mathrm{TF} \rightarrow \mathrm{LP} \rightarrow \mathrm{TR}$ & 0.240 & 0.071 & 7.945 & $\mathrm{H} 4$ & * & Accepted \\
\hline
\end{tabular}

$*, p<0.001$ 
TABLE 6: Mediation analysis through Sobel's $t$.

\begin{tabular}{|c|c|c|c|c|c|c|c|}
\hline Path tested & $a$ & Standard error $(a)$ & $b$ & Standard error $(b)$ & Sobel test & Aroian test & Goodman test \\
\hline $\mathrm{TF} \rightarrow \mathrm{LP}$ & 0.833 & 0.071 & - & - & - & - & - \\
\hline $\mathrm{LP} \rightarrow \mathrm{IT}$ & - & - & 0.112 & 0.035 & - & - & - \\
\hline $\mathrm{TF} \rightarrow \mathrm{LP} \rightarrow \mathrm{IT}$ & - & - & - & - & $3.087 *$ & $3.077 *$ & $3.098 *$ \\
\hline
\end{tabular}

$*, p<0.01$.

TABLE 7: Direct, indirect and total effects of trade facilitation on international trade mediated by logistics performance.

\begin{tabular}{|c|c|c|c|c|c|c|c|c|}
\hline \multirow[t]{2}{*}{ Variable } & \multirow[t]{2}{*}{$\bar{b}$} & \multirow[t]{2}{*}{$p$} & \multirow[t]{2}{*}{ Standard error } & \multirow{2}{*}{$\begin{array}{c}\text { Lower limit } \\
\text { confidence interval }\end{array}$} & \multirow{2}{*}{$\begin{array}{c}\text { Upper limit } \\
\text { confidence level }\end{array}$} & \multicolumn{3}{|c|}{ Bootstrap results for indirect effect } \\
\hline & & & & & & $\begin{array}{l}\text { Lower confidence } \\
\text { interval }\end{array}$ & effect & $\begin{array}{c}\text { Upper confidence } \\
\text { interval }\end{array}$ \\
\hline Total effect & 0.0507 & 0.2495 & 0.0439 & -0.0357 & 0.1370 & - & - & - \\
\hline Direct effect & -0.0428 & 0.4113 & 0.0520 & -0.1452 & 0.0596 & - & - & - \\
\hline Indirect effect & 0.0935 & 0.0019 & 0.0301 & 0.0344 & 0.1525 & - & - & - \\
\hline Result & - & - & - & - & - & 0.0325 & 0.0935 & 0.1543 \\
\hline
\end{tabular}

Note: Bootstrap samples: 1000

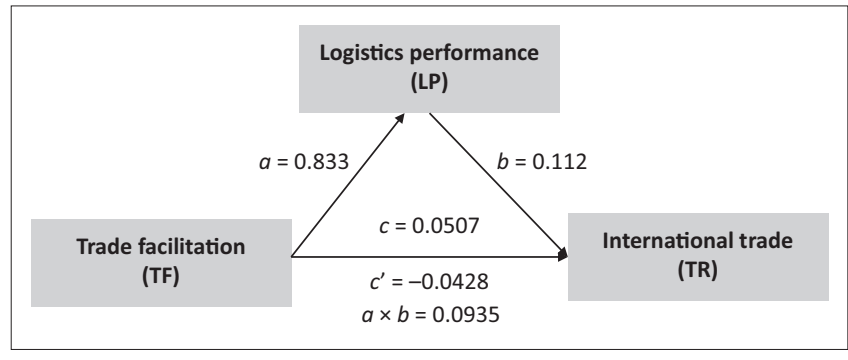

$a$, path from TF to LP; $b$, path from LP to TR; $c$, total effect; $c^{\prime}$, direct effect; $a \times b$, indirect effect.

FIGURE 3: Standardised $\beta$-coefficient in logistics performance partially mediated pathway from trade facilitation to international trade.

The direct effect is -0.043 (the path coefficient from trade facilitation to international trade). The indirect effect is derived from the product of the path coefficient resulting from trade facilitation to logistic performance and the path coefficient from logistic performance to international trade: $(0.833)(0.112)=0.0935$. The total effect represents the sum of the direct effect and the indirect effect: (0.0935) $+(-0.0428)=0.0507$.

\section{Discussion and conclusion} Theoretical implications

In this study, we focused on the relationship between trade facilitation and international trade through logistics performance. The main finding suggests that logistics performance mediates the relationship between trade facilitation and international trade. In other words, the relationship between trade facilitation and international trade is found to be positive and statistically significant when it is associated with logistics performance.

So far, psychology remains the field that has more research taking into account the mediated effects (Baron \& Kenny 1986; Mussel 2019). Relationship quality mediates the association between cultural intelligence and institutional success. Mediation analysis also helps managers to develop strategies to enhance their international market orientations in order to increase performance (Nakos, Dimitratos \& Elbanna 2019).
In the field of trade, few studies have been carried out on this issue. Munim and Schramm (2018) focused on the plausible contribution of seaborne trade, from a partial infrastructure quality and logistics performance perspective. Indeed, efficient logistics helps trade facilitation to achieve its objectives, which is to increase trade through the reduction of all kinds of additional costs. The logistics performance is found to be an important enabler to trade (Tang \& Abosedra 2019). This study is unique in dealing with logistics as the mediator between trade facilitation and international trade, given the absence of studies that highlight logistics performance in the context of trade at the national and international levels.

According to Baron and Kenny (1986), the reason why the relationship between trade facilitation and international trade is considered non-significant is because the first step doesn't reveal anything to mediate. This statement has been criticised by several researchers, mainly by Shrout and Bolger (2002), who suggested moving to the next step if there is a thorough theoretical background about their relationship even if there is no significant association between $X$ and $Y$. The other steps, therefore, indicate the indirect effect of trade facilitation on international trade through logistics performance.

Another important implication of our study is what MacKinnon et al. (2007) call an inconsistent mediation since the sign of the direct effect $\left(c^{\prime}\right)$ is opposed to the sign of the indirect effect $(a \times b)$. Indeed, the failure to meet step 1 and the existence of mediation means that the mediating variable (LP) acts as a suppressive variable. Likewise, Hoyle and Kenny (1999) perceive this mediation as proximal mediation, given that $a=0.833$ is greater than $b=0.112$ (effects of normalisation). Our result is more similar to the example of the relationship between stress and mood as mediated by coping. In principle, the direct effect is negative: the more trade facilitation, the worse international trade. However, the fact that the effect of trade facilitation on logistics performance is positive (more trade facilitation, more logistics performance) and the effect of logistics performance on international trade is positive (better logistics performance, 
better international trade), means that the indirect effect is positive. The total effect of trade facilitation on international trade is then likely to be very small because the direct and indirect effects will attempt to neutralise each other.

\section{Managerial implications}

This study reminds policymakers and logistics service providers of the need for regulatory reforms in the logistics sector as a bridge to connecting small businesses to international markets. The management of international flows of goods, as well as related documentation and payments, aims to reduce direct and indirect logistics costs through the simplification and harmonisation of procedures and documentation. Otherwise, the limited availability of these services leads to a reduction in the volume of trade flows. For these reasons, this study encourages policymakers in developing and least developed countries to improve their domestic trade competitiveness by promoting positive policy reforms in the logistics and transport sectors. In a context of competition, the interaction between public and private actors, and strengthening trade and investment support institutions can truly make a significant difference.

Policymakers and managers can take advantage of these results, since logistics has been shown to have a crucial role in SCM, and recent studies have also revealed that the improvement of the logistics sector enables increasing the volume of trade. This study also confirmed that through quality logistics, trade tends to increase considerably more than without quality logistics. This suggests that trade performance measures need to be taken into consideration by countries, particularly middle-income countries, to develop the import and export process and optimise the supply chain in order to increase trade more efficiently and effectively.

\section{Limitations}

As no other study so far has addressed the mediating role of the logistics performance between trade facilitation and international trade, it remains challenging to conclude from the previous literature. Therefore, we encourage researchers to take an interest in this question and to guide future research on the role that SCM could have on international trade due to its very secure connection with logistics.

Additionally, the data for this research come mainly from lower-middle-income and upper-middle-income countries. Future research can extend on a large database by adding low-income and high-income countries. Moreover, the variables were constructed from the data we collected from different sources; those unobserved, hidden or latent cannot be directly measured in the research. To remedy this problem, we carried out several tests in order to validate the data. However, future research should use variables that can be observed and directly measured.
The mediation analysis is not only restricted to linear regression. It is also conducted using logistic regression or polynomial regression, and more. Besides, several other variables and relationships can be added, for example moderated mediation or mediated moderation. Future research can extend by testing the effects of two or multiple mediators, for example indirect effects for M1 (SCM) and M2 (trade barriers) on international trade.

\section{Conclusion}

This study attempted to analyse the role of logistics performance in the relationship between trade facilitation and international trade. Firstly, we used SEM to assess unobservable latent constructs. Following Baron and Kenny's (1986) four steps, we applied Sobel's (1990) test and bootstrapping to see if the effect of mediation is statistically significant or not. The Sobel test was chosen because it was widely used before, and bootstrapping because its use was strongly recommended in recent years.

Larson et al. (2012) have argued that logistics, including transport, has a direct effect on prices and trade in local markets as it determines the performance and adaptability of supply chains, particularly in African and Middle Eastern countries that are highly dependent on food imports. In developing countries, especially poor and landlocked countries, transport and logistics account for $20 \%-60 \%$ of the price of products at the point of delivery and constitute $48 \%$ of the cost of maize imported from the United States by Nicaragua (Arvis, Marteau \& Raballand 2010). Our research results show that the empirical evidence does not support the conclusion that there are direct links between trade facilitation and international trade. In contrast, it provides evidence of indirect links between trade facilitation and the international trade with which logistics performance is associated. In sum, logistics performance mediates the relationship between trade facilitation and international trade. However, logistics performance acts as a suppressive variable, and this mediation is qualified as incoherent and proximal mediation.

Lower-middle income countries should follow the example of upper-middle income countries by encouraging cooperation between the public and private sectors and focus their efforts on all aspects of the development of transport and infrastructure services capable of improving logistics performance in order to enhance and facilitate the flow of international trade. Nevertheless, this finding needs to be reassessed by other methods, and additional data sets should be collected in the future.

\section{Acknowledgements}

First, I thank the founder and director of the Institute of Transport and Logistics and all members of the Institute of Transport and Logistics of Hunan University for their help, support and sympathy. 


\section{Competing interests}

The authors declare that they have no competing interest in this publication.

\section{Authors' contributions}

A.D.Y. is the main author of the manuscript; he undertook the literature review, developed the theoretical framework, collected and analysed the data from the different sources. A.D. is the co-author of this manuscript; she approved the research idea, supported the empirical data analysis, gave suggestions and comments. Both authors read and approved the final manuscript.

\section{Ethical consideration}

This article followed all ethical standards for carrying out research.

\section{Funding information}

This research was financially supported by the project of the National Social Science Fund of China (No. 18BJY168).

\section{Data availability statement}

Data sharing is not applicable to this article as no new data were created or analysed in this study.

\section{Disclaimer}

The views and opinions expressed in this article are those of the authors and do not necessarily reflect the official policy or position of any affiliated agency of the authors.

\section{References}

Alfes, K., Shantz, A.D., Truss, C. \& Soane, E.C., 2013, 'The link between perceived human resource management practices, engagement and employee
behaviour: A moderated mediation model, The International Journal of behaviour: A moderated mediation model', The International Journal of
Human Resource Management 24(2), 330-351. https://doi.org/10.1080/0958 Human Resource Man
5192.2012.679950

Alwin, D.F. \& Hauser, R.M., 1975, 'The decomposition of effects in path analysis', American Sociological Review 40(1), 37-47. https://doi.org/10.2307/2094445

Ariekot, C., 2018, Overlapping trade agreements: Stepping stones or stumbling blocks? Lund University Libraries, Lund. Available from http://lup.lub.lu.se/ student-papers/record/8936145.

Arvis, J.F., Marteau, J.F. \& Raballand, G., 2010, The cost of being landlocked: Logistics costs and supply chain reliability, The World Bank, Washington, DC.

Bagozzi, R.P., Yi, Y. \& Phillips, L.W., 1991, 'Assessing construct validity in organizational research', Administrative Science Quarterly 36(3), 421-458. https://doi. org/10.2307/2393203

Banister, D. \& Berechman, Y., 2001, 'Transport investment and the promotion of economic growth', Journal of Transport Geography 9(3), 209-218. https://doi. org/10.1016/S0966-6923(01)00013-8

Baron, R.M. \& Kenny, D.A., 1986, 'The moderator-mediator variable distinction in social psychological research: Conceptual, strategic, and statistical considerations', Journal of Personality and Social Psychology 51(6), 1173. https://doi. org/10.1037/0022-3514.51.6.1173

Behar, A. \& Venables, A.J., 2011, 'Transport costs and international trade', in A. de Palma (ed.), Handbook of transport economics, Edward Elgar Publishing, Northampton, MA, pp. 97-115.

Bensassi, S., Márquez-Ramos, L., Martínez-Zarzoso, I. \& Suárez-Burguet, C., 2015 'Relationship between logistics infrastructure and trade: Evidence from Spanish regional exports', Transportation Research Part A: Policy and Practice 72(February) 47-61. https://doi.org/10.1016/j.tra.2014.11.007

Bolumole, Y.A., 2001, 'The supply chain role of third-party logistics providers', The International Journal of Logistics Management 12(2), 87-102. https://doi. org/10.1108/09574090110806316
Clark, X., Dollar, D., \& Micco, A., 2004, 'Port efficiency, maritime transport costs, and bilateral trade. Journal of development economics', 75(2), 417-450.

Cromley, J.G. \& Azevedo, R., 2007, 'Testing and refining the direct and inferential mediation model of reading comprehension', Journal of Educational Psychology 99(2), 311. https://doi.org/10.1037/0022-0663.99.2.311

Cronbach, L.J., 1951, 'Coefficient alpha and the internal structure of tests', Psychometrika 16(3), 297-334. https://doi.org/10.1007/BF02310555

Devlin, J. \& Yee, P., 2005, 'Trade logistics in developing countries: The case of the Middle East and North Africa', World Economy 28(3), 435-456. https://doi org/10.1111/j.1467-9701.2005.00620.x

Drolet, A.L. \& Morrison, D.G., 2001, 'Do we really need multiple-item measures in service research?', Journal of Service Research 3(3), 196-204. https://doi. org/10.1177/109467050133001

Fairchild, A.J. \& MacKinnon, D.P., 2009, 'A general model for testing mediation and moderation effects', Prevention Science 10(2), 87-99. https://doi.org/10.1007/ s11121-008-0109-6

Gani, A., 2017. 'The logistics performance effect in international trade', The Asian Journal of Shipping and Logistics 33(4), 279-288. https://doi.org/10.1016/j. ajsl.2017.12.012

Gonçalves, W. \& Assumpção, M.R.P., 2016, 'Structural equation modeling for multivariate statistical analysis of the relationship between ports and regional economy', Revista Técnica de la Facultad de Ingeniería Universidad del Zulia 39(7), 126-133. https://doi.org/10.21311/001.39.7.16

Hanouz, M.D., Geiger, T. \& Doherty, S., 2014, Global enabling trade report, World Economic Forum, Geneva.

Hausman, W.H., Lee, H.L. \& Subramanian, U., 2013, 'The impact of logistics performance on trade', Production and Operations Management 22(2), 236-252. https://doi.org/10.1111/j.1937-5956.2011.01312.x

Hoogland, J.J. \& Boomsma, A., 1998, 'Robustness studies in covariance structure modeling: An overview and a meta-analysis', Sociological Methods \& Research 26(3), 329-367. https://doi.org/10.1177/0049124198026003003

Hoyle, R.H. \& Kenny, D.A., 1999, 'Sample size, reliability, and tests of statistical mediation', Statistical Strategies for Small Sample Research 1, 197-223

Itakura, K., 2014, 'Impact of liberalization and improved connectivity and facilitation in ASEAN', Journal of Asian Economics 35(December), 2-11. https://doi. org/10.1016/j.asieco.2014.09.002

Iwanow, T. \& Kirkpatrick, C., 2007, 'Trade facilitation, regulatory quality and export performance', Journal of International Development: The Journal of the Development Studies Association 19(6), 735-753. https://doi.org/10.1002/ jid.1399

Jöreskog, K.G., 1970, 'A general method for estimating a linear structural equation system', ETS Research Bulletin Series 1970(2), i-41. https://doi. org/10.1002/j.2333-8504.1970.tb00783.x

Kaiser, H.F., 1974, 'An index of factorial simplicity', Psychometrika 39(1), 31-36. https://doi.org/10.1007/BF02291575

Kali, R., Méndez, F. \& Reyes, J., 2007, 'Trade structure and economic growth', The Journal of International Trade \& Economic Development 16(2), 245-269. https:// doi.org/10.1080/09638190701325649

Kline, R.B., 2005, Principles and practice of structural equation modelling, 2nd edn., Guilford, New York, NY.

Korinek, J. \& Sourdin, P., 2011, 'To what extent are high-quality logistics services trade facilitating?' OECD trade policy working papers 108, OECD Publishing, Paris.

Lakshmanan, T.R., 2011, 'The broader economic consequences of transport infrastructure investments', Journal of Transport Geography 19(1), 1-12. https:// doi.org/10.1016/j.jtrangeo.2010.01.001

Lakshmanan, T.R., Subramanian, U., Anderson, W.P. \& Leautier, F.A., 2001, Integration of transport and trade facilitation: Selected regional case studies, The World Bank, Washington, DC.

Larson, D.F., Lampietti, J., Gouel, C., Cafiero, C. \& Roberts, J., 2012, Food security and storage in the Middle East and North Africa, The World Bank, Washington, DC.

MacKinnon, D.P., Fairchild, A.J. \& Fritz, M.S., 2007, 'Mediation analysis', Annual Review of Psychology 58, 593-614. https://doi.org/10.1146/annurev.psych.58.110405. 085542

Mann, C.L., 2012, 'Supply chain logistics, trade facilitation and international trade: A macroeconomic policy view', Journal of Supply Chain Management 48(3), 7-14. https://doi.org/10.1111/j.1745-493X.2012.03270.x

Martí, L., Puertas, R. \& García, L., 2014, 'The importance of the logistics performance index in international trade', Applied Economics 46(24), 2982-2992. https://doi. org/10.1080/00036846.2014.916394

Martinez-Zarzoso, I. \& Márquez-Ramos, L., 2008, 'The effect of trade facilitation on sectoral trade', The BE Journal of Economic Analysis \& Policy 8(1). https://doi. org/10.2202/1935-1682.1927

Messerlin, P.A. \& Zarrouk, J., 2000, 'Trade facilitation: Technical regulations and customs procedures', World Economy 23(4), 577-593. https://doi. org/10.1111/1467-9701.00291

Meyer, J.P. \& Smith, C.A., 2000, 'HRM practices and organizational commitment: Test of a mediation model', Canadian Journal of Administrative Sciences/Revue canadienne des sciences de l'administration 17(4), 319-331. https://doi. org/10.1111/j.1936-4490.2000.tb00231.x 
Milner, C., Morrissey, O. \& Zgovu, E., 2008, Trade facilitation in developing countries (No. 08/05), CREDIT Research Paper, University of Nottingham, Nottingham.

Munim, Z.H. \& Schramm, H.J., 2018, 'The impacts of port infrastructure and logistics performance on economic growth: The mediating role of seaborne trade', Journal of Shipping and Trade 3(1), 1. https://doi.org/10.1186/s41072-018-0027-0

Mussel, P., 2019, 'From needs to traits: The mediating role of beliefs about control', Personality and Individual Differences 151(December), 109525. https://doi. org/10.1016/j.paid.2019.109525

Muthén, L.K. \& Muthén, B.O., 2002, 'How to use a Monte Carlo study to decide on sample size and determine power', Structural Equation Modeling 9(4), 599-620. https://doi.org/10.1207/S15328007SEM0904_8

Nakos, G., Dimitratos, P. \& Elbanna, S., 2019, 'The mediating role of alliances in the international market orientation-performance relationship of smes', International Business Review 28(3), 603-612. https://doi.org/10.1016/j.ibusrev.2018.12.005

Njinkeu, D., Wilson, J.S. \& Fosso, B.P., 2008, Expanding trade within Africa: The impact of trade facilitation, The World Bank, Washington, DC.

Pagel, D., 1999, 'Managing for optimal performance through effective coordination of the supply chain', Production and Inventory Management Journal 40(1), 66.

Paruzel, R., 2018, 'Exchanging goods and services across international borders. Technological progress in commerce facilitation', Młoda Humanistyka 11(1). Available from http://humanistyka.com/index.php/MH/article/view/142.

Pérard, E., 2009, 'Water supply: Public or private? An approach based on cost of funds, transaction costs, efficiency and political costs', Policy and Society 27(3), 193-219. https://doi.org/10.1016/j.polsoc.2008.10.004

Pomfret, R. \& Sourdin, P., 2010, 'Trade facilitation and the measurement of trade costs', Journal of International Commerce, Economics and Policy 1(1), 145-163. https://doi.org/10.1142/S179399331000010X

Portugal-Perez, A. \& Wilson, J.S., 2009, 'Why trade facilitation matters to Africa', World Trade Review 8(3), 379-416. https://doi.org/10.1017/\$147474560900439X

Portugal-Perez, A. \& Wilson, J.S., 2012, 'Export performance and trade facilitation reform: Hard and soft infrastructure', World Development 40(7), 1295-1307. https://doi.org/10.1016/j.worlddev.2011.12.002

Puertas, R., Martí, L. \& García, L., 2014, 'Logistics performance and export competitiveness: European experience', Empirica 41(3), 467-480. https://doi. org/10.1007/s10663-013-9241-z

Raballand, G., Refas, S., Beuran, M. \& Isik, G., 2012, 'Why cargo dwell time matters in trade, Economic Premise no. 81, World Bank, Washington, DC.
Ricardo, D., 1817, On the principles of political economy and taxation, Penguin Books, London.

Shrout, P.E. \& Bolger, N., 2002, 'Mediation in experimental and nonexperimental studies: New procedures and recommendations', Psychological Methods 7(4), 422. https://doi.org/10.1037/1082-989X.7.4.422

Smith, A., 1776, An inquiry into the nature and causes of the wealth of nations, vol. 1 , printed for W. Strahan; and T. Cadell, London.

Sobel, M.E., 1990, 'Effect analysis and causation in linear structural equation models', Psychometrika 55(3), 495-515. https://doi.org/10.1007/BF02294763

Stone, S. \& Strutt, A., 2010, 'Transport infrastructure and trade facilitation in the Greater Mekong Subregion', in D.H. Brooks (Ed.), Trade facilitation and regiona cooperation in Asia, Edward Elgar, Cheltenham, 156-191.

Tang, C.F. \& Abosedra, S., 2019, 'Logistics performance, exports, and growth: Evidence from Asian economies', Research in Transportation Economics 78(December), 100743. https://doi.org/10.1016/j.retrec.2019.100743

Tinsley, H.E. \& Tinsley, D.J., 1987, 'Uses of factor analysis in counseling psychology research', Journal of Counseling Psychology 34(4), 414. https://doi. org/10.1037/0022-0167.34.4.414

Weerahewa, J., 2009, 'Impact of trade facilitation measures and regional trade agreements on food and agricultural trade in South Asia (No. 69)', ARTNeT Working Paper Series, UNESCAP, Bangkok.

Wilson, J., Mann, C. \& Otsuki, T., 2003, Trade facilitation and economic development Measuring the impact, The World Bank, Washington, DC.

Wilson, J.S., Mann, C.L. \& Otsuki, T., 2005, 'Assessing the benefits of trade facilitation: A global perspective', World Economy 28(6), 841-871. https://doi. org/10.1111/j.1467-9701.2005.00709.x

World Economic Forum, 2020, The World Bank's 2020 country classification explained, viewed n.d., from https://www.weforum.org/agenda/2020/08/worldbank-2020-classifications-low-high-income-countries/

Yang, C.C. \& Chang, Y.K., 2019, 'Crucial factors influencing international logistics operations for African landlocked countries - A case study of Burkina Faso', Maritime Policy \& Management 46(8), 939-956. https://doi.org/10.1080/030888 39.2019.1606464

Yanikkaya, H., 2003, 'Trade openness and economic growth: A cross-country empirical investigation', Journal of Development Economics 72(1), 57-89. https://doi. org/10.1016/S0304-3878(03)00068-3 


\section{Appendix 1}

TABLE 1-A1: List of countries.

\begin{tabular}{|c|c|}
\hline Lower-middle-income & Upper-middle-income \\
\hline Armenia & Albania \\
\hline Bangladesh & Algeria \\
\hline Bolivia & Angola \\
\hline Cambodia & Azerbaijan \\
\hline Cameroon & Bosnia and Herzegovina \\
\hline Cote d'Ivoire & Botswana \\
\hline Egypt & Brazil \\
\hline El Salvador & China \\
\hline Ghana & Bulgaria \\
\hline Guatemala & Colombia \\
\hline Guyana & Costa Rica \\
\hline Honduras & Dominican Republic \\
\hline India & Ecuador \\
\hline Indonesia & Jamaica \\
\hline Kenya & Jordan \\
\hline Kyrgyz Republic & Kazakhstan \\
\hline Lesotho & Lebanon \\
\hline Mauritania & Malaysia \\
\hline Moldova & Mauritius \\
\hline Morocco & Mexico \\
\hline Myanmar & Mongolia \\
\hline Nicaragua & Montenegro \\
\hline Nigeria & Namibia \\
\hline Pakistan & Paraguay \\
\hline Philippines & Peru \\
\hline Sri Lanka & Romania \\
\hline Ukraine & Russian Federation \\
\hline Vietnam & Serbia \\
\hline Zambia & South Africa \\
\hline- & Thailand \\
\hline - & Tunisia \\
\hline- & Turkey \\
\hline- & Venezuela \\
\hline
\end{tabular}

Source: Based on World Economic Forum, 2020, The World Bank's 2020 country classification explained, viewed n.d., from https://www.weforum.org/agenda/2020/08/world-bank-2020classifications-low-high-income-countries/ 